\title{
Importance of estuary morphology for ecological connectivity with their adjacent coast: A case study in Brazilian tropical estuaries
}

\author{
Pelage Latifa 1, *, Gonzalez Júlio Guazzelli 1, 2, Leloch François ${ }^{3}$, Ferreira Valdimere ${ }^{1}$, \\ Munaron Jean-Marie ${ }^{3}$, Lucena-Frédou Flávia ${ }^{1}$, Frédou Thierry ${ }^{1}$
}

1 Universidade Federal Rural de Pernambuco, UFRPE, Departamento de Pesca e Aquicultura, Rua Dom Manuel de Medeiros, s/n, Recife, PE. CEP: 52.171-900, Brazil

2 MARBEC, Univ. Montpellier, CNRS, IRD, Ifremer, Montpellier, France

3 IRD, Laboratoire des Sciences de L'Environnement Marin, UMR 6539, CNRS, UBO, IRD, Ifremer, 29280, Plouzané, France

* Corresponding author : Latifa Pelage, email address : latifa.pelage3@gmail.com

\begin{abstract}
:
Coastal habitats are interlinked by ecological connectivity, defined as the exchange of organic matter or organisms between habitats. The degree of this connectivity will depend in particular on the geometric properties of the landscape. The increasing anthropogenic alterations in estuaries therefore raises the need to understand how their morphological characteristics influence fluxes between habitats. We used stable isotopes to investigate the variability of ecological connectivity between three estuaries and their adjacent coastal areas by tracking the origin of the organic matter (estuarine vs coastal) underlying the diet of the migrant species Eucinostomus argenteus. The chosen estuaries were geomorphologically distinct, exhibiting, in particular, differences in their degree of connection to the sea, corresponding to the morphological features (shape, mouth width) controlling key physico-chemical variables in this habitat (e.g. salinity). The sampling of the basal food sources contributing to the food web was performed in the three estuaries and in their adjacent coasts. The variability in stable isotope ratios between estuaries was examined for both fish and sources of organic matter. In the three estuaries, Bayesian models were applied for each season (dry and rainy) to quantify the relative contribution of sources from estuarine and coastal environments supporting the diet of the silver mojarra. The share of coastal organic matter increased with the degree of sea connection, indicating that the properties of the seascape can regulate the intensity of interactions between ecosystems. Variations in ecological connectivity are likely to affect the functioning of ecosystems as they influence trophic pathways and energy flows between adjacent habitats. Morphological modifications could thus significantly disturb ecosystems by altering the structure of food web, thereby affecting certain ecosystem services such as the availability of living marine resources.
\end{abstract}




\section{Highlights}

- The origin of the organic matter underlying food webs was investigated in three estuaries with distinct morphologies. Coastal organic matter contributed more to fish diet when landscape properties enabled a better sea-connection. Estuary morphology regulates interactions between estuaries and their adjacent coast. 


\section{Introduction}

The emergence of seascape ecology brought the need to consider coastal habitats as a single continuum rather than as separate biomes ( Green et al., 2012; Berkström et al., 2013). This conceptual change aimed at a more integrated management of the coastal zone (Beger et al., 2010). In particular, addressing the connectivity between habitats is essential for fisheries management because coastal habitats provide complementary ecological functions that are critical for marine living resources (Sheaves, 2009). Coastal habitats should therefore not be considered as isolated patches in which different sub-populations occur, since a comprehensive view reflects population dynamics more accurately (Burgess et al., 2014).

Ecosystem interactions can be primarily subdivided into biological, chemical and physical interactions (Ogden, 1997). The connectivity degree between coastal habitats will depend in particular on the geometric properties of the landscape (Olds et al., 2017). More specifically, landscape characteristics affect ecological connectivity which consists of the Interactions between ecosystems through the movement of organisms and the exchange of nutrients and organic matter that are involved in ecological processes within these systems. (Nagelkerken, 2009). Previous work demonstrated that variability in the geometric characteristics of the seascape, such as the distance between habitats, can affect the intensity of flows between habitats (Mumby et al., 2004; Berkström et al., 2013).

Estuaries include a wide range of different transitional water bodies with distinct landscape characteristics (Flemming, 2011). Thereby, the classification of estuaries requires the consideration of physico-chemical variables such as hydrodynamics and bathymetry, as they determine not only the dynamics and structure of the sediments, but also the nature of the primary producers (Elliott \& McLusky, 2002; Whitfield \& Elliott, 2011). Consequently, the morphology of estuaries and, in particular, the set of geometrical variables controlling the degree of sea water dilution in the estuary (like depth and mouth width), could have an influence on ecological connectivity. This morphological variability, which can be viewed as their degree of connection to the sea, is likely to enhance or prevent flows with adjacent coastal habitats. In addition, estuarine morphologies suffer from increasing anthropic alterations, such as the construction of polders, harbours or dykes which can drastically change the sedimentary dynamics and the composition of estuarine 
biological communities (Wetzel et al., 2012; Du et al., 2016; Lechêne et al., 2018). It is thus relevant to investigate how estuarine morphological characteristics influence interactions between habitats. The implications of this variability in terms of ecosystem functioning need to be taken into account before deciding to modify seascape features or implement restoration measures through eco-engineering (Elliott et al., 2016).

Understanding ecological connectivity involves studying energy pathways in food webs and their intrinsic trophic relationships in order to assess community structure and functional role of species living in the ecosystems (Pasquaud et al., 2010; França et al., 2011). Hence, estuarine food webs can be described by characterizing trophic relationships, sources of organic matter and energy flows between system components (Pasquaud et al., 2008). In these complex and dynamic ecosystems, food webs can be supported by the production of various local primary producers, as well as the transport of organic matter from adjacent coastal and riverine areas (Choy et al., 2009; Selleslagh et al., 2015). However, identifying the origin of the organic matter at the base of estuarine fish food web can be difficult, in particular because conventional methods like gut content analysis provide only a snapshot of the diet at a given time (Pasquaud et al., 2008 ; Pasquaud et al., 2010; França et al., 2011). Moreover, gut analyses do not enable a comprehensive food web analysis to reliably track the source of the organic matter underlying the diet of high trophic level consumers that do not feed directly on primary producers.

Stable isotope methods produce estimates of trophic position that can both capture complex trophic interactions and track energy flows between habitats (Carvalho et al., 2017; Whitney et al., 2018; Gonzalez et al., 2019). Since a consumer's stable isotope ratios reflect the values of its food sources, trophic position assessment is possible if the differences in isotopic composition between an animal and its prey, i.e. trophic level enrichment, are known (Caut et al., 2009). Indeed stable isotopes of nitrogen $\left(\delta^{15} \mathrm{~N}\right)$ and carbon $\left(\delta^{13} \mathrm{C}\right)$ have been successfully used to study ecosystem functions and food webs (Le et al., 2018). $\delta^{15} \mathrm{~N}$ can constitute a proxy for the trophic position of an organism since it increases considerably with the trophic level (Post, 2002; Caut et al., 2009). On the other hand, $\delta^{13} \mathrm{C}$ differs substantially between primary producers (Post, 2002; Herzka, 2005), providing an overview of the origin of organic matter (Fry, 2006) . 
In estuaries, the origin of organic matter has already been studied with stable isotopes and a high contribution of marine basal sources has been highlighted in some studies (Pasquaud et al., 2008; Selleslagh et al., 2015). Nevertheless, other studies conducted in estuaries have shown that in situ primary production can outweigh other food sources and contribute significantly to fish growth (Lobry et al., 2008). Therefore, knowledge on the extent of ecological connectivity between estuaries and their adjacent coastal areas is essential for designing the scale of conservation measures, particularly in the case of migratory species using multiple habitats (Vasconcelos et al., 2010; Reis-Santos et al., 2018).

Migratory species constitute a good proxy to study ecological connectivity between two habitats since their movements represent linkages across the seascape (Selleslagh et al., 2015). In this study, we chose Eucinostomus argenteus Baird \& Girard (1855) to investigate the intensity of the flows between habitats. The silver mojarra is a member of the Gerreidae family comprising species with complex life strategies that are important for artisanal fisheries in north-eastern Brazil (Pinto et al., 2013). E. argenteus is one of the main Gerreidae in the region and can be classified as an estuarine-dependent species, as its juveniles are found in great abundance in the estuarine habitats (Potter et al., 2013) where they reside since their reduced size at this ontogenetic stage (less than $13.5 \mathrm{~cm}$ ) (Bouchon-Navaro et al., 2006) does not allow them to make large migrations (Franco et al., 2012). In those habitats, they were classified as second-order consumers, feeding opportunistically as well on microcrustaceans (amphipods, copepods, tanaidaceous, ostracods) as on detritus with variations in the proportion and frequency of different items according to their ontogeny and food availability (Chi-Espínola et al., 2018). Although adults of these species are more abundant in adjacent coastal areas (Ramos et al., 2016), they use estuaries as a feeding ground, predating mostly on Bivalvia siphons and polychaetes (Vasconcellos et al., 2018) or as a reproductive ground (Chaves and Bouchereau, 2000). The degree of ecological connectivity between estuaries and adjacent coast would be reflected by the dominant origin of the carbon sources (coastal vs estuarine origin) on which the species diet is based.

The objective of this study is to understand the variability in ecological connectivity between estuarine and coastal habitats. We are thus investigating the flows between three morphologically distinct estuaries and their adjacent coastal areas by tracking the origin of the organic matter (coastal or estuarine) underlying the 
diet of E. argenteus. Our hypothesis is that geomorphological disparities between estuaries influence the origin of the organic matter that supports the E. argenteus regime, based on the assumption that flows are enhanced in the estuaries most connected to the sea.

\section{Material and Methods}

\subsection{Study Area}

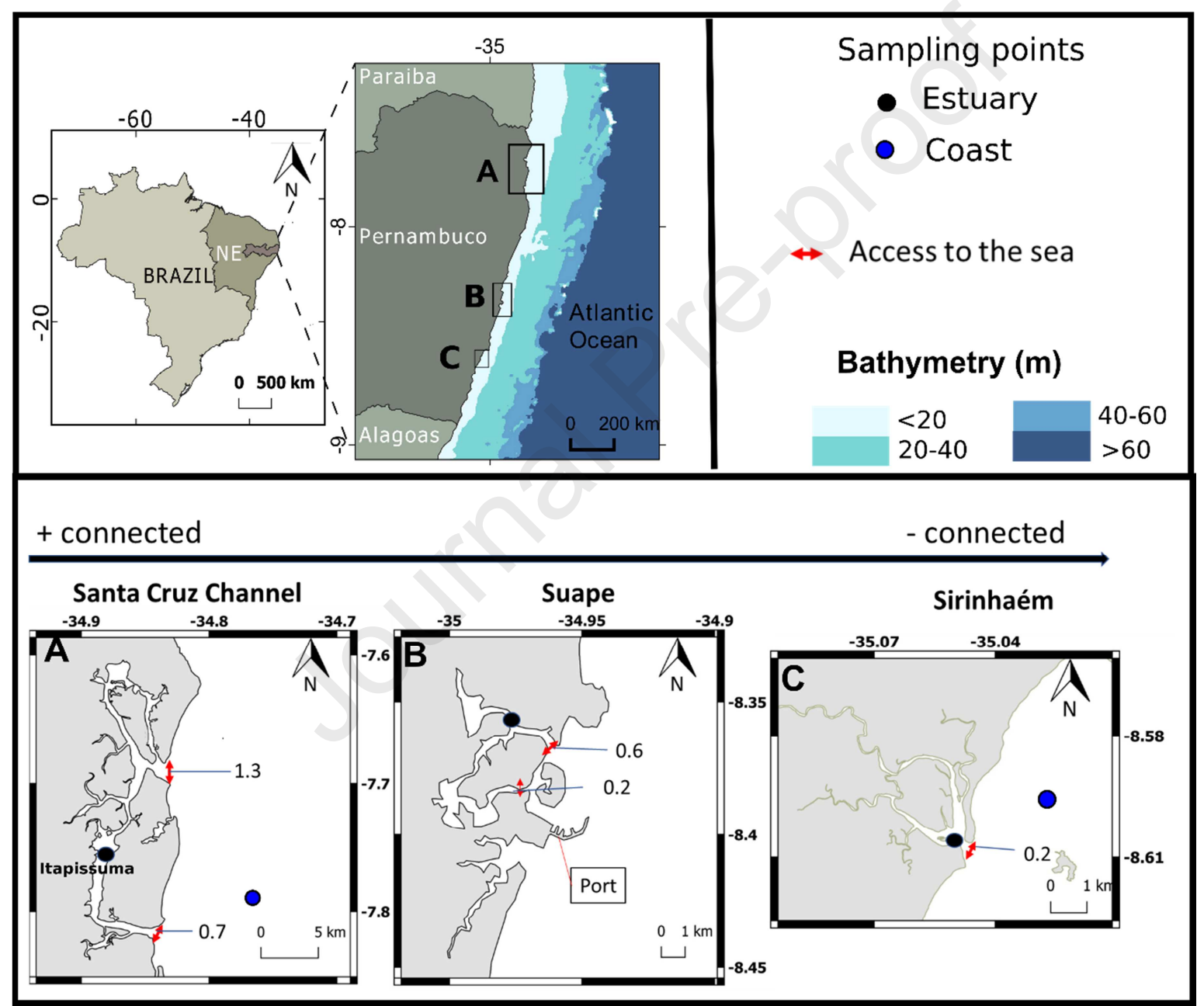

Figure 1: Map of the area under study showing the three estuaries (Santa Cruz Channel, Suape and Sirinhaém) and their adjacent coast where sampling was performed in the state of Pernambuco, Brazil. The widths of the mouths are indicated in kilometers for each estuary to show their geomorphological disparities, providing them with different degrees of connection with the sea.

The area under study encompasses estuarine areas and shallow coastal waters of the continental shelf of the state of Pernambuco, Brazil (Figure 1). This narrow continental shelf ( $35 \mathrm{~km}$ on average), is characterized by shallow and warm waters (typically $26-29^{\circ} \mathrm{C}$ ), soft slope, shelf break between 50 and $60 \mathrm{~m}$, high salinity (>36) and a sedimentary cover composed of carbonatic and terrigenous sediments (Manso et al., 2003; 
Assunção et al., 2020). Three estuaries, the Santa Cruz Channel, Suape and Sirinhaem, were chosen because of their diverse morphological characteristics, which differ in particular in the geometric variables controlling the degree of dilution of the sea water in the estuary (such as the depth and width of the mouth) (Table 1, Figure 1). This different degree of connection to the sea is manifested notably by a difference in salinity (Table 1).

Table 1: Summary of morphological characteristics and anthropogenic activities of the three estuaries along the coast of Pernambuco, Brazil.

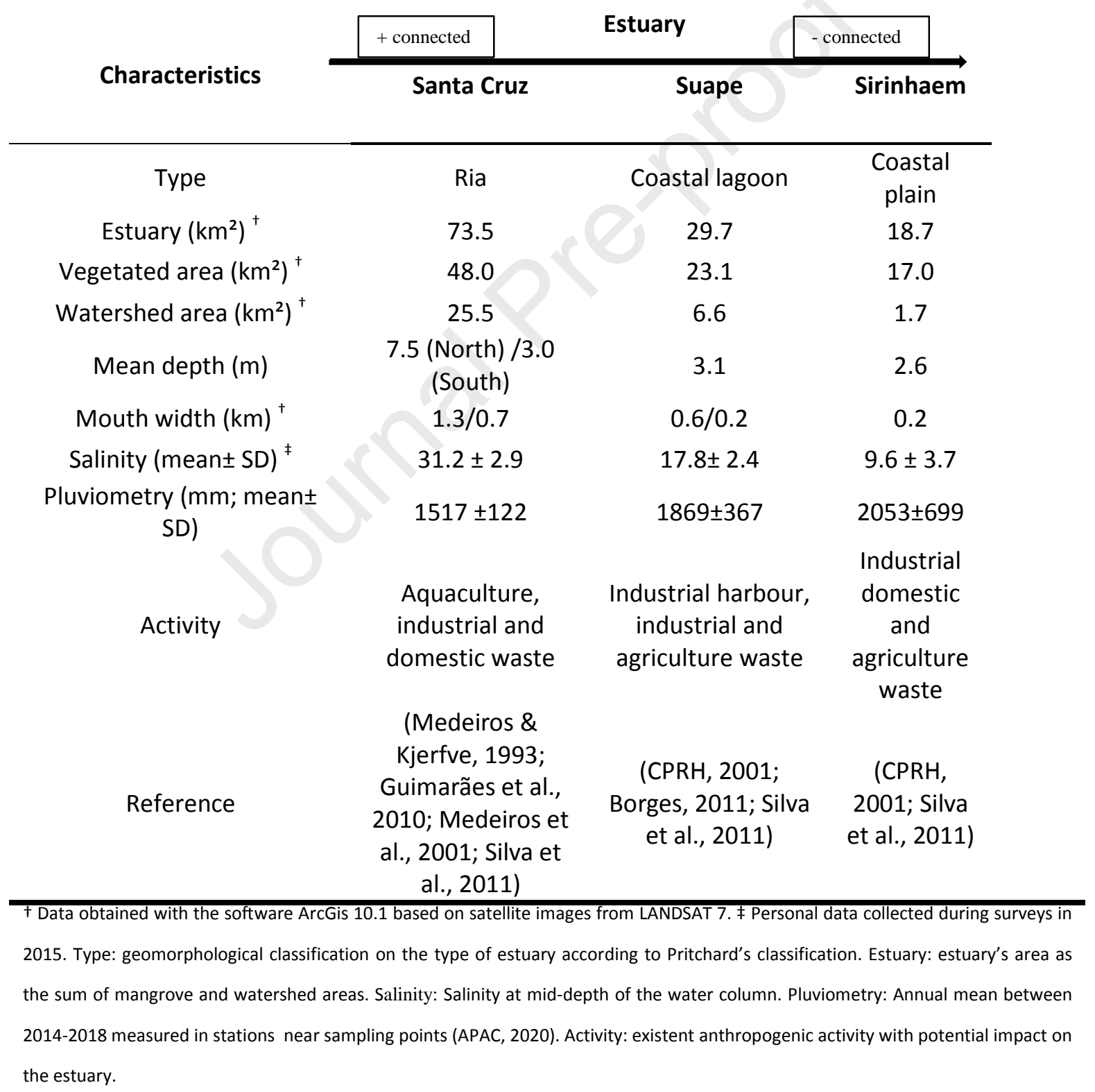

The Santa Cruz Channel is located on the north coast and forms the largest estuarine complex in Pernambuco. It displays a U-shaped surface area of $22 \mathrm{~km}$ and has two accesses to the Atlantic Ocean (Silva 
et al., 2011). These two mouths are $0.7 \mathrm{~km}$ and $1.3 \mathrm{~km}$ wide, respectively, providing it with a high degree of connection with the open sea, resulting in high salinity (Table 1). In addition, the city of Itapissuma is the main fishing centre of Pernambuco, and also one of the most touristic destinations of the region. (Quinamo, 2006). Aquaculture, artisanal fishing, industry and agriculture are all important anthropogenic activities in the area (Moura and Candeias, 2009).

The Suape estuary, situated in the south coast, is a coastal lagoon with a flattened geomorphological shape (Santos and Costa, 1974). The geomorphological and hydrodynamic conditions were altered by the construction of the port in 1979 (Muniz et al., 2005). The generated landfills blocked the flow of two of the four rivers that previously drained into the Suape estuary. Suape is now formed by two main rivers that flow into a large brackish lagoon and has a restricted connection to the ocean.

Also located in the south littoral of Pernambuco, Sirinhaem is the smallest estuary among the three and presents the narrowest connection to the sea (CPRH 2001). This enclosed lagoon exhibits low salinity and low depth (Table 1). Artisanal fishing, agroindustry and trade are important socio-economic activities in the zone (Valença et al., 2010).

\subsection{Sampling}

\subsubsection{Fish and baseline}

E. argenteus was captured in the three estuaries above described, in shallow areas (Figure 1). The specimens were collected in 2015 from March to August and from September to January, which represent the local rainy and dry seasons, respectively (Medeiros et al., 2001) with the help of local fishermen using artisanal fishing gears. All gears characteristics are detailed in the Supplementary Table 1. After identification, all fish were measured to the nearest millimetre (Total length) and weighed to the nearest gram. In addition, a long-lived primary consumer (mangrove oyster Crassostrea rhizophorae) was collected to represent the baseline for estimating the trophic position of E. argenteus.

\subsubsection{Organic matter sources}

Organic matter sources were sampled in the estuaries, to provide a background of stable isotope ratios at the base of E. argenteus diet. Since mojarras are characterized by their highly protrusible mouth which they use to feed on items they remove from the sediment (Chen et al., 2007), sources associated to the benthic 
system were selected. Thus, macroalgae (Sargassum sp. and Ulva sp.), microphytobenthos, rotten mangrove leaves and particulate organic matter in the sediment (SOM) were collected along with seagrass when present in the area.

The SOM was also collected from the adjacent coast (shallow coastal waters) of the Santa Cruz Channel and Sirinhaem to measure the influence of coastal sources. However, as an industrial port is settled in the coast in front of the Suape estuary, the sampling of the coastal SOM could not be realized due to the restricted access to the area. We thus chose to use the coastal SOM isotopic ratios of Sirinhaem as a proxy for Suape considering the vicinity of the two areas.

The rotten mangrove leaves, seagrass and macroalgae were picked up manually during low tide. The SOM was collected from the first $2 \mathrm{~mm}$ layer of sediment while microphytobenthos (i.e. benthonic microalgae) was sampled from the sediment surface at low tide and extracted in the laboratory.

\subsection{Isotope analysis}

For stable isotopic analysis, a fragment of dorsal white muscle from each fish was extracted and cleaned with distilled water to remove any remaining scales or bones. The isotope analysis of the basal sources was performed on the whole collected sample. The material was dried in an oven at $60^{\circ} \mathrm{C}$ for 48 hours. Then, dried samples were grinded into a homogeneous fine powder with a mortar and pestle. The SOM samples were divided into two subsamples. One was acidified to remove inorganic carbon before the $\delta^{13} \mathrm{C}$ analysis and the other was used for $\delta^{15} \mathrm{~N}$ analysis (Pinnegar and Polunin, 1999). Analysis of the carbon and nitrogen isotope ratios were performed at the Pôle de Spectrométrie Océan (PSO - IUEM, Plouzané, France) with an elemental analyzer (Thermo Flash 2000, interface Thermo ConFio IV) interfaced to a mass spectrometer (Thermo Delta $\mathrm{V}+$ ).

The isotope ratio for carbon $\left(\delta^{13} \mathrm{C}\right)$ and nitrogen $\left(\delta^{15} \mathrm{~N}\right)$ were calculated from the relation between the sample isotopic value and a known standard:

$\delta^{13} \mathrm{C}$ or $\delta^{15} \mathrm{~N}=[($ Rsample $/$ Rstandard $)-1] \times 1000$.

In this equation, $R$ represents the ratio ${ }^{13} \mathrm{C} /{ }^{12} \mathrm{C}$ or ${ }^{15} \mathrm{~N} /{ }^{14} \mathrm{~N}$. The $\mathrm{R}$ standard is relative to international standards, the Air and V-PDB (Vienna PeeDee Belemnite) for nitrogen and carbon, respectively. The 
precision of the analysis was monitored through a known standard (Thermo - Acetanilide) every six samples and defined as $\pm 0.11 \%$ o (standard error) and $\pm 0.07 \%$ for carbon and nitrogen, respectively.

\subsection{Statistical Analyses}

All the statistical analyses were performed with the software R version 3.5.2 (R Core Team, 2019). Mann Whitney tests were carried out to determine if there were any differences in $\delta^{13} \mathrm{C}$ and $\delta^{15} \mathrm{~N}$ between the estuarine and coastal SOM. Spearman ranking tests correlation tests were performed to examine the relationship between fish $\delta^{13} \mathrm{C}$ or $\delta^{15} \mathrm{~N}$ and total fish length in each estuary separately and for all estuaries together. Mann Whitney tests were applied to check whether the $\delta^{13} \mathrm{C}$ and $\delta^{15} \mathrm{~N}$ of the fish varied seasonally in each estuary.

The trophic positioning of Eucinostomus argenteus was determined using the tRophicPosition package ("tRophicPosition: Bayesian Trophic Position Calculation with Stable Isotopes" (Quezada-Romegialli et al., 2018).The trophic position estimate is influenced by the baseline's representativeness of the target consumer food chain (Post, 2002). In view of the zoobenthivorous diet of the species studied, we proposed an estimate based on a long-lived filter feeder as a reference base (C. rhizophorae).

Kruskal-Wallis tests together with Dunn's post hoc tests were used to see if there were differences of $\delta^{13} \mathrm{C}$ and $\delta^{15} \mathrm{~N}$ for the fish and the baseline (C. rhizophorae) among the different estuaries.

Moreover, the Standard Elliptical Area (SEA) method was applied to compare the isotopic composition of the fish caught in each estuary. The SEA encompasses about $40 \%$ of the data (mean and standard deviation of covariables $\delta^{13} \mathrm{C}$ and $\delta^{15} \mathrm{~N}$ ) and provides an appropriate method for comparing the isotope niche (variability in isotope ratios) of groups belonging to several communities by eliminating extreme values that would bias the analysis if only the amplitude was considered (Jackson et al., 2011). The SEAc (corrected standard ellipse area) was calculated to overcome the underestimation for small sample sizes (Jackson et al. 2011). The SEAc was estimated for each estuary and season. These analyses were performed with the Stable isotope Bayesian analysis in $\mathrm{R}$ (SIBER) package (Jackson et al., 2017).

Bayesian stable isotope mixing models, using the MixSiar package (Stock \& Semmens, 2015) were built to estimate the relative contributions of basal sources to $E$. argenteus diet in each estuary. MixSiar allows the inclusion of covariates to better understand the variance among both consumer and source tracer values 
(Stock et al., 2018). As estuarine environments are highly dynamic, the factor season was added for both the fish and the sources. The use of separate models for each season would have increased the residual error (Stock et al., 2018). The input data were ratios of carbon and nitrogen from fish along with the respective mean and standard deviations of sources for a given estuary and season. When sources were not significantly different between seasons, the annual average for both the rainy and dry seasons was used. Mixing models are highly influenced by the selection of a proper trophic enrichment factor (TEF) (Parnell et al., 2010). The TEF consists in the isotopic fractionation from source to consumer (Post, 2002). Since this TEF varies with both the diet and the habitat (Bunn, Leigh, and Jardine 2013), we chose a TEF proper to apply between estuarine zoobenthivorous fish (which is a second-degree consumer) and its basal sources of organic matter (primary producers): $2.0 \pm 0.6 \%$ and $5.6 \pm 1.5 \%$ for $\delta{ }^{13} \mathrm{C}$ and $\delta{ }^{15} \mathrm{~N}$, respectively (see Kostecki et al., 2012; Selleslagh et al., 2015). As the $\delta^{15} \mathrm{~N}$ of fish in each estuary were not significantly different between seasons (Supplementary Table 2), the same TEF was applied for both seasons assuming that $E$. argenteus fed at the same trophic levels during the dry and rainy seasons. The signatures of the sources after application of TEF were represented on the same two-dimensional space as the isotope ratios of the consumers in order to verify a geometric prerequisite for the execution of Mixsiar. The mixing models were only run when the consumer isotope ratios were within the mixing polygon bounded by the base source signatures representing the trophic limits of the system (Phillips and Gregg, 2003).

\section{Results}

\subsection{Fish isotopic variability and trophic position}

A total of 46 samples of E. argenteus, 25 C. rhizophorae samples and 112 of basal food sources had their $\delta^{13} \mathrm{C}$ and $\delta^{15} \mathrm{~N}$ isotope values analysed (Supplementary Table 2 and 3). Estuarine fish size ranged from 3.6 $\mathrm{cm}$ (in Suape) to $16.6 \mathrm{~cm}$ (in Sirinhaem) (Figure 2). The size of the fish was not correlated to their $\delta^{15} \mathrm{~N}$ nor their $\delta^{13} \mathrm{C}$ values when considering all estuaries together (Supplementary Table 4). However, fish size in the Santa Cruz Channel was positively correlated with their $\delta^{15} \mathrm{~N}$ values and the fish size in Suape were negatively correlated with their $\delta^{13} \mathrm{C}$ (Supplementary Table 4, Figure 2). 


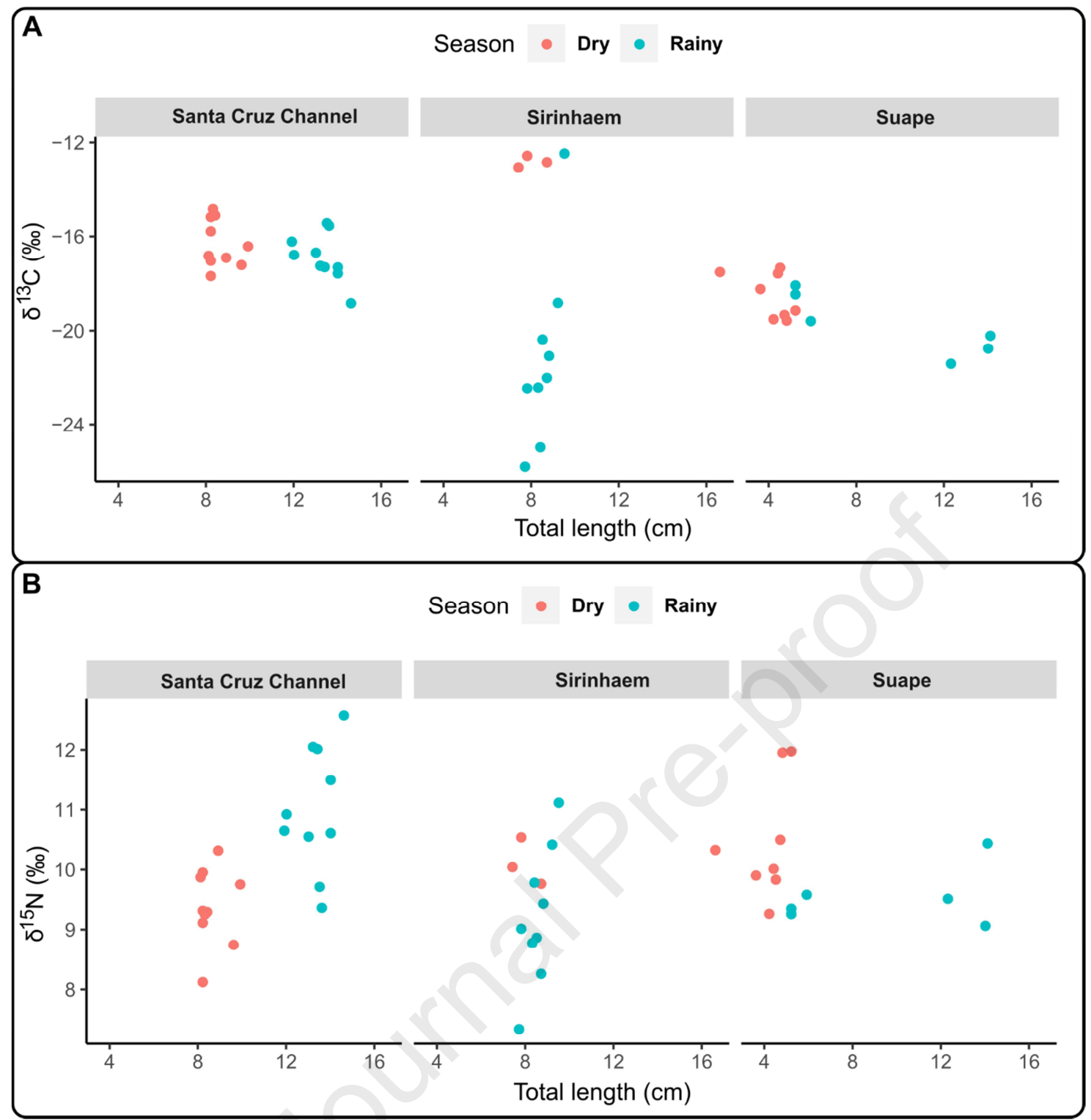

Figure 2: Biplot showing A) the $\delta^{13} \mathrm{C}$ and $\mathrm{B}$ ) the $\delta^{15} \mathrm{~N}$ of fish according to their total length in in each estuary (Santa Cruz Channel, Sirinhaem and Suape) during both seasons (dry and rainy).

Seasonal variations in terms of $\delta^{15} \mathrm{~N}$ were only observed for fish captured in the Santa Cruz Channel (Supplementary Table 5). Seasonal differences in $\delta^{13} \mathrm{C}$ were detected only for Sirinhaem (Supplementary Table 5, Figure 2, 3). In addition, Sirinhaem was the only estuary where the ellipses of both seasons did not overlap. However, the overlap between the rainy and dry ellipses was small for Suape and the Santa Cruz Channel.

Sirinhaem ellipse during the rainy season completely overlaps the Suape ellipse for the rainy season and overlapped an important part of Suape ellipse for the dry season. Sirinhaem fish collected during the rainy season had the most depleted $\delta^{13} \mathrm{C}$, followed by the Suape fish in both seasons (Figure 3) while the $\delta^{13} \mathrm{C}$ of 
the Santa Cruz Channel fish caught in both seasons exhibited more enriched $\delta^{13} \mathrm{C}$ values, comparable to those of the coastal SOM. Fish caught in Sirinhaem during the dry season had the highest values of $\delta^{13} \mathrm{C}$. The most elevated values of SEAc were observed for Sirinhaem during the rainy season $\left(10.1 \%{ }^{2}\right)$. All the other estuaries /seasons values exhibited low SEAc (between 1.9 and $3.7 \%{ }^{2}$ ).

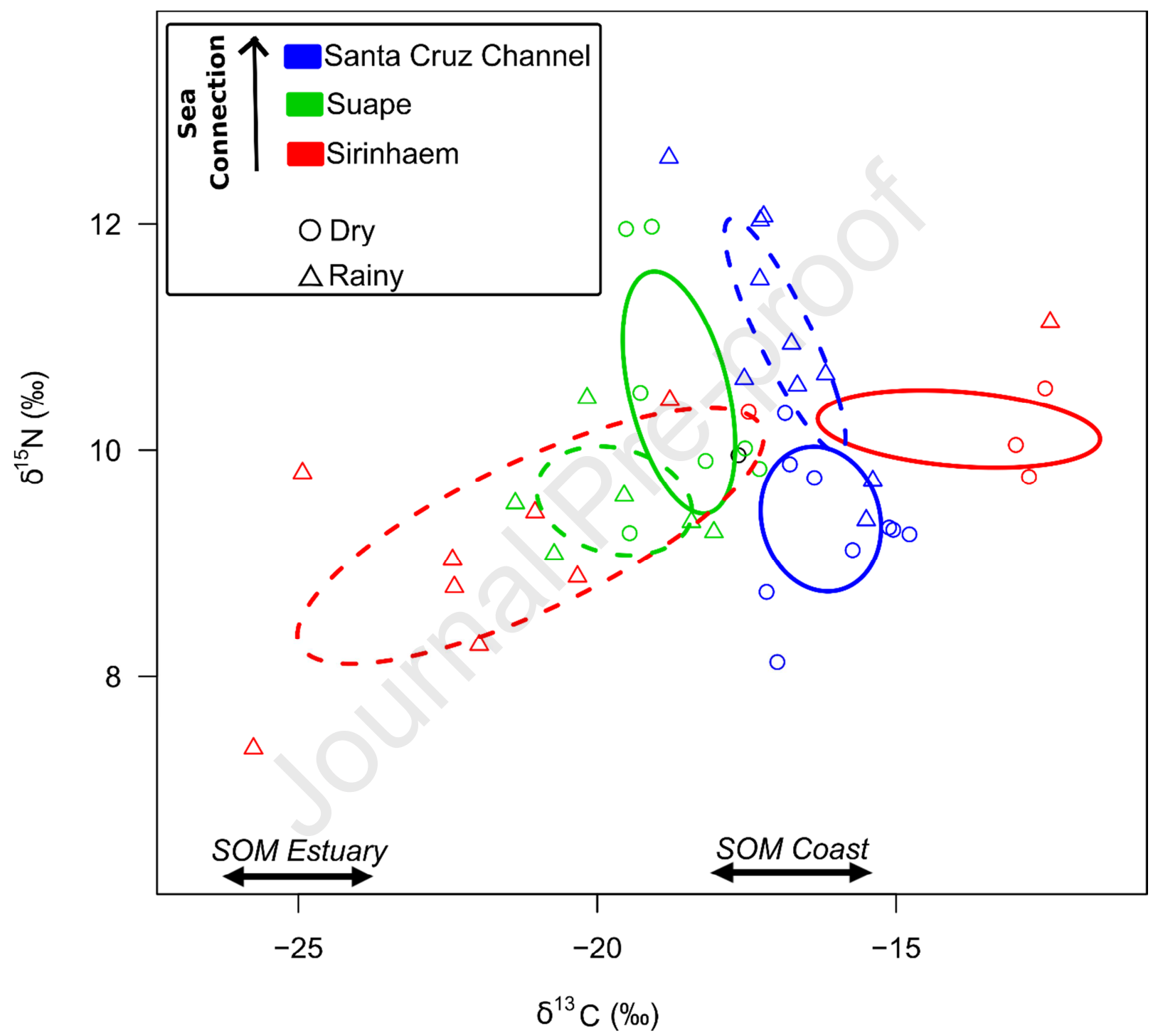

Figure 3: Fish standard ellipses of the three estuaries during both dry (solid line) and rainy (dashed line) seasons. The black points represent the fish sampled in coastal areas which are plotted to highlight the differences in the degree of connection to the sea among the three estuaries (Santa Cruz Channel, Suape and Sirinhaem). The $\delta 13 \mathrm{C}$ values of the SOM collected in estuaries $(-25 \pm 1.2 \%)$ and at the coast $(-17$ $\pm 1.6 \%$ ) are shown in the graph to give an indication of the $\delta 13 \mathrm{C}$ values at the base of each environment.

The $\delta^{15} \mathrm{~N}$ values of the fish among estuaries were not significantly different (Kruskal-Wallis chi-squared = 1.9052, $\mathrm{p}$-value $>0.05$ ) whereas $\delta^{13} \mathrm{C}$ values varied depending on the estuaries (Kruskal-Wallis chi-squared $=$ 14.458, $\mathrm{df}=2, \mathrm{p}$-value $<0.05)$ and the Santa Cruz Channel was significantly different from Suape and 
Sirinhaem (Dunn's test, $\mathrm{p}$-value $<0.05$ ).Likewise, the $C$. rhizophorae $\delta^{15} \mathrm{~N}$ did not exhibit differences among estuaries (Kruskal-Wallis chi-squared $=5.6029, \mathrm{df}=2, \mathrm{p}$-value $>0.05$ ) but their $\delta^{13} \mathrm{C}$ were different (KruskalWallis chi-squared $=15.382, \mathrm{df}=2, \mathrm{p}$-value $>0.05)$. The trophic positions of $E$. argenteus were similar among the estuaries: $2.78 \pm 0.17$ in Sirinhaem, $2.75 \pm 0.14$ in Suape and $2.66 \pm 0.11$ in the Santa Cruz Channel.

3.2 Sources contributions to E. argenteus diet 

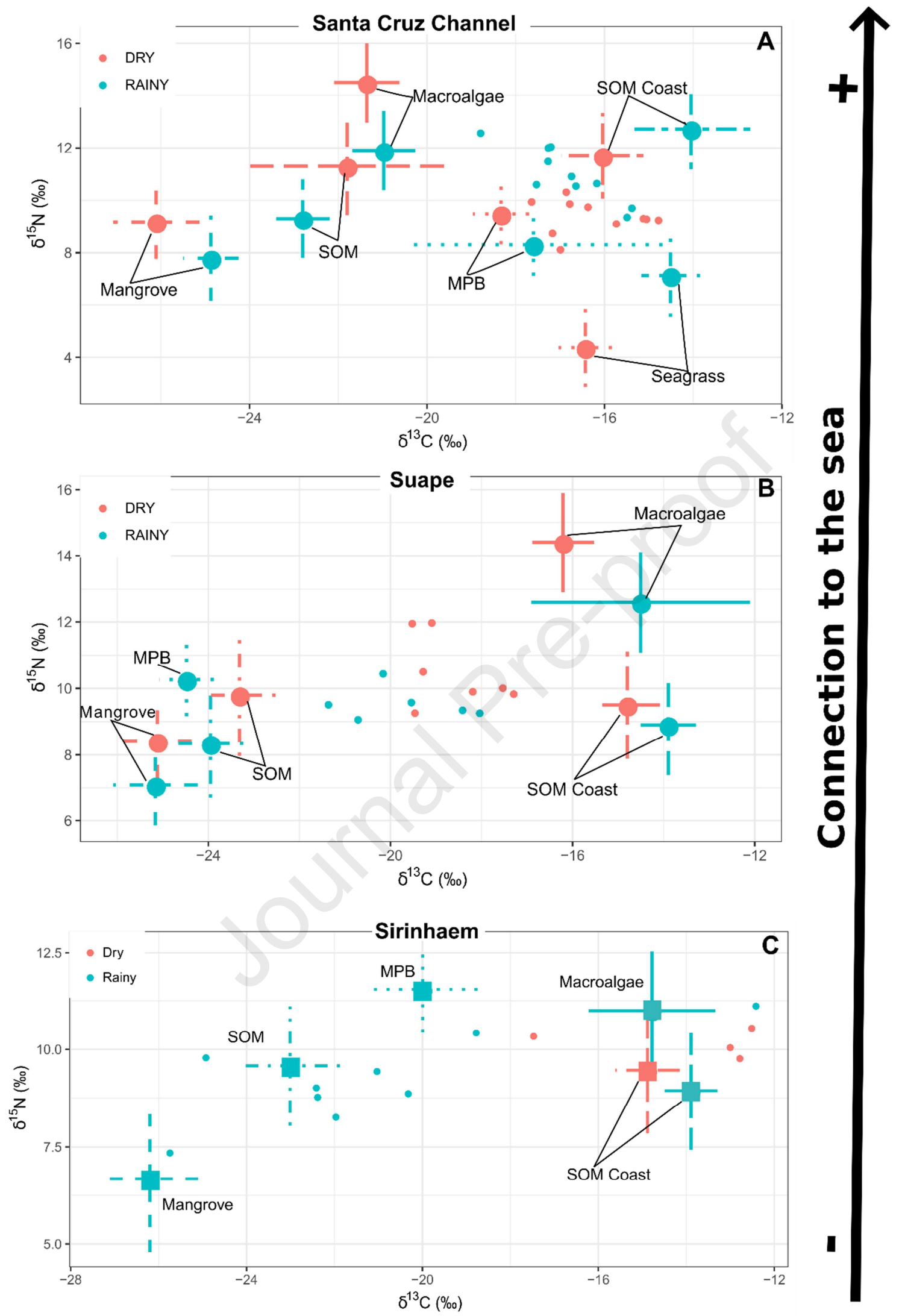

Figure 4: Dual plots of the sources (represented by the squares and whiskers showing mean values $\pm S D$ of the $\delta^{13} \mathrm{C}$ and $\delta^{15} \mathrm{~N}$ ) and the consumers (represented by the points) after applying the trophic enrichment factor to the basal sources in the three estuaries (Santa Cruz Channel, Suape and Sirinhaem). SOM: Sedimentary organic matter; mangrove: mangrove leaves; MPB: microphytobenthos. 
In all three estuaries, several basal sources exhibited overlapping isotopic signatures (Figure 4). Indeed, the macroalgae ratios were close to those of the SOM in the Santa Cruz Channel while in Suape, depending on the season, both the microphytoplankton and mangrove leaves signatures were similar to the isotopic ratios of the estuarine SOM. Likewise, in Sirinhaem, the macroalgae overlapped the coastal SOM during the dry season. Most of the Sirinhaem fish ratios during the dry season were close to those of the macroalgae and the coastal SOM but were distant from the other sources. During the dry season, most of the Sirinhaem $E$. argenteus points displayed on the dual plot were outside the mixing polygon delimited by the basal sources. This pattern suggests that the selected sources were not appropriate to adequately describe the organic matter that supports the diet of E. argenteus. Thus, the MixSiar model was run only for the rainy season in this estuary. 

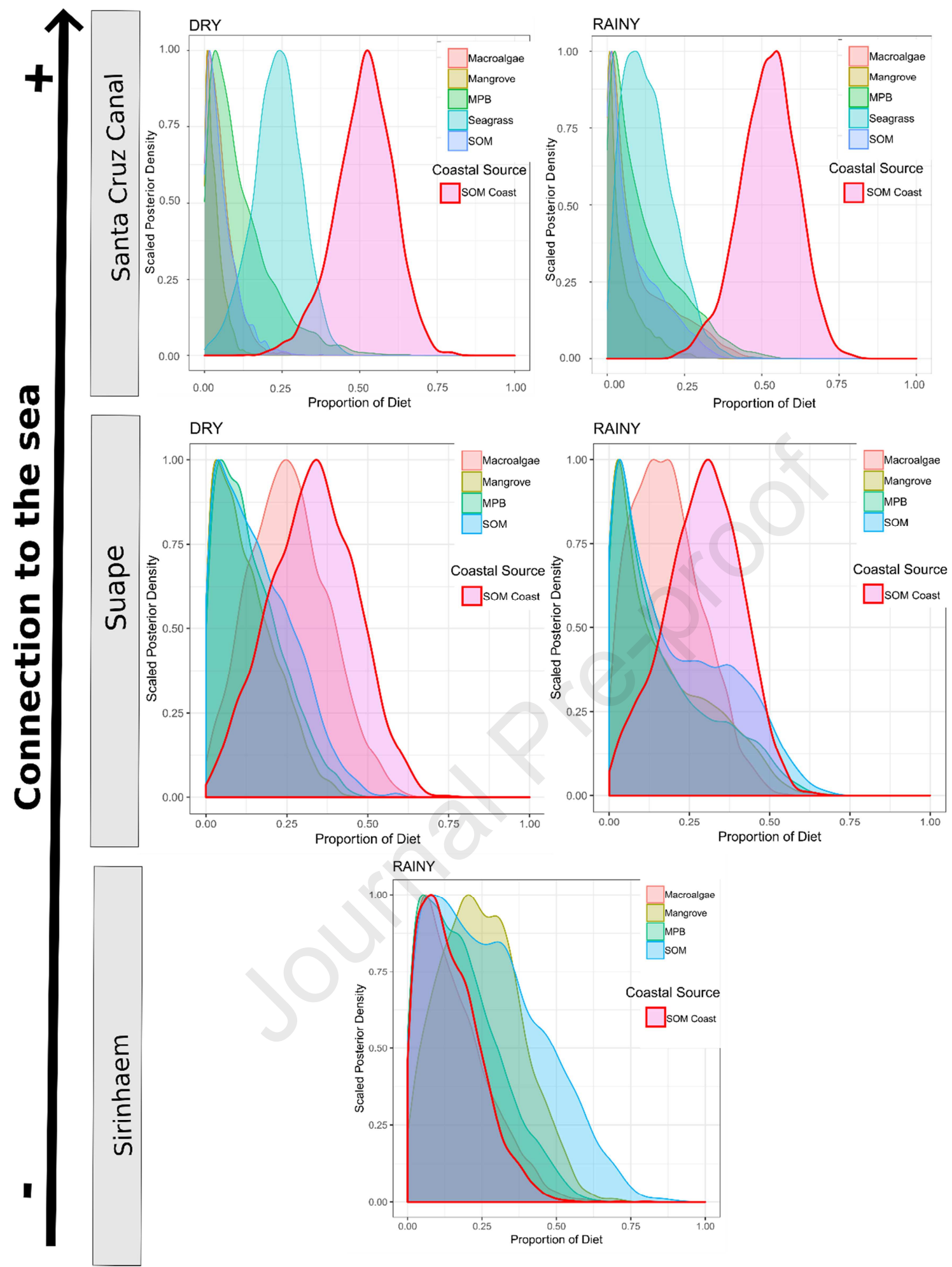

Figure 5: Density plots representing seasonal proportion of the basal sources in the diet of $E$. argenteus at the Santa Cruz Channel, Suape and Sirinhaem. SOM: Sedimentary organic matter; mangrove: mangrove leaves; MPB: microphytobenthos.

Overall, the relative contributions of the basal sources were different between estuaries (Figure 5, Supplementary Table 6). The proportion of coastal source compared to estuarine sources increased with the sea connection (Figure 5, 6 and Supplementary Table 6). The relative contribution of the coastal source is high in Santa Cruz Channel, lower in Suape and minimal in Sirinhaem (Figure 5, 6). 
The contribution of the coastal SOM in the Santa Cruz Channel was the largest in both seasons, accounting for slightly more than $50 \%$ of the diet of $E$. argenteus. During the dry season, the seagrass had an important contribution during the dry season ( $23 \%)$ whereas it contributed less during the rainy season (13\%). The microphytobenthos contribution was also relevant in both dry and rainy season (around $12 \%$ ). The other sources contributions are low (less than $10 \%)$.

The coastal SOM had also the highest contribution during both seasons in Suape attaining the value of 32\% during the dry season and $29 \%$ during the rainy season, but its relative participation was less substantial than in the Santa Cruz Channel. The other sources with relevant contribution in that area were the macroalgae during the dry season (25\%), and the SOM in the rainy season (20\%). The contributions of the other sources were similar, fluctuating between 10 and $20 \%$.

On the other hand, in Sirinhaem, the Coastal SOM exhibited the lowest contribution during the rainy season. No sources contribution was higher than $30 \%$. The two sources with relevant contribution were the estuarine SOM (27\%) and the mangrove leaves (24\%). The rest of the source contributions varied between 10 and $20 \%$. Yet, the amplitude of the curves expressed a high variability among individuals.

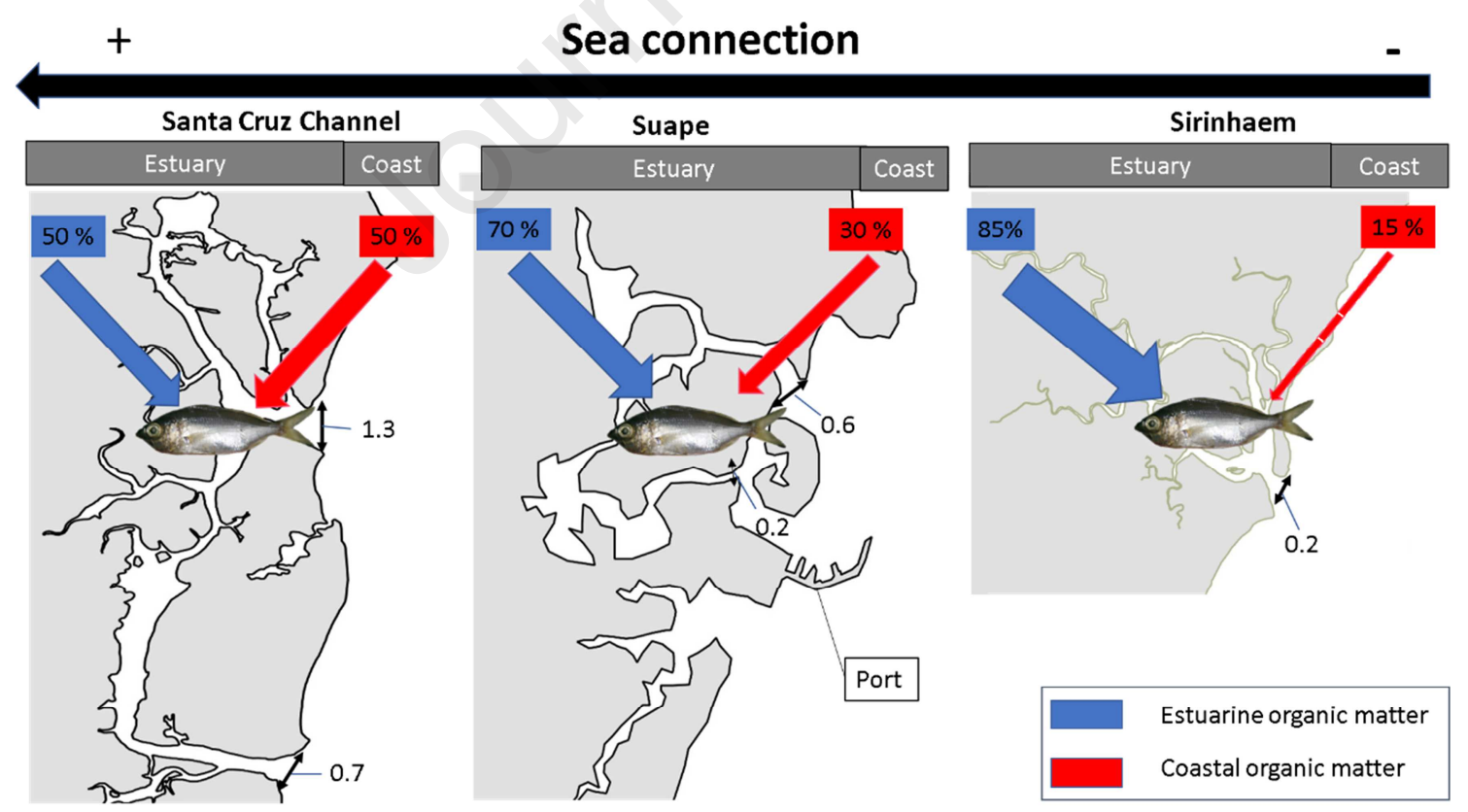

Figure 6: Conceptual model summarizing the relative contribution of estuarine and coastal organic matter supporting the diet of $E$. argenteus in the three estuaries studied. In Sirinhaem, the relative contributions of organic matter correspond only to the rainy season. 


\section{Discussion}

\subsection{Landscape properties and ecological connectivity}

Our study showed that $E$. argenteus diet varied between the three estuaries studied and that the contribution of coastal resources increased with the connection to the sea. This connection with the sea, embodied by the morphological features (shape, mouth width) controlling key physico-chemical variables in this habitat (depth, salinity), is thus a suitable indicator of the connectivity between estuarine and coastal habitat. Thereby, ecological connectivity was promoted by the high sea connection in the Santa Cruz Channel. The fish of this estuary had high $\delta^{13} \mathrm{C}$ values and the coastal SOM was therefore the source that contributed most to the diet.

The coastal SOM was also important in Suape but to a lesser extent since the geomorphological alterations, induced by the construction of the port, resulted in a restricted land-sea connection, isolating the two environments. The landfills caused by the dredging have led to a reduction in the river regime and hence to sedimentation, as well as to a reduction in water exchange and depth (Muniz et al., 2005). In Sirinhaem, estuarine sources were predominant, showing that ecological connectivity is reduced in this enclosed lagoon during the rainy season.

Tracing the origin of basal sources of organic matter was important to illustrate the complexity of trophic pathways between coasts and estuaries. In addition, E. argenteus was an appropriate indicator to provide information on the ecological connectivity between these two systems, since the adults $(>13 \mathrm{~cm})$ that inhabit preferentially coastal areas, enter the estuaries to feed (Ramos et al., 2016). Thus, no correlation was found between the $\delta^{13} \mathrm{C}$ and the sizes of the fish in Sirinhaem or in the Santa Cruz Channel while the larger individuals in Suape presented depleted $\delta^{13} \mathrm{C}$ values, characteristics of estuarine sources (Moens et al., 2002). This corroborates the fact that adults of this species use estuaries as a feeding area, as is the case for many species of the Gerreidae family (Ramos et al., 2012).

Though the movements performed by adult fish might exacerbated the connectivity patterns, local variations in marine intrusion are likely to explain the gradient of connectivity seen in the three estuaries. Organisms that have limited mobility can be influenced by this connectivity as estuarine food webs can be supported by coastal organic matter (Selleslagh et al., 2015). Methods using only stable isotopes cannot 
separate the effect of fish movement from the effect of marine intrusion. A tagging study with artificial loggings would have provided information on the frequency of foraging movements (Olds et al., 2017) and would have helped to distinguish these two components of ecological connectivity. Yet, the influence of ontogenetic migrations on the results seems to be reduced since fish sizes were not correlated to their respective $\delta^{13} \mathrm{C}$ and $\delta^{15} \mathrm{~N}$ values when the three estuaries were grouped. Thus, differences in diet observed among estuaries cannot be attributed to differences in fish size. Furthermore, although fish sizes differed from one estuary to another, trophic positions were similar among estuaries. However, the low trophic position values found in this study (about 2.7) could be due to the tendency of trophic position underestimation with isotopic methods (Hussey et al., 2014) . Indeed, studies in the region of study did find a trophic position a little higher (i.e. 2.95) (Lira et al., 2018)) and diet studies in estuaries classified $E$. argenteus as a second degree consumer (Chi-Espínola et al., 2018; Vasconcellos et al., 2018).

Coastal and estuarine sources have been successfully distinguished using Bayesian mixing models. This analysis, despite the need for careful parameterisation, remain the best method for quantifying the relative contributions of sources in a diet (Parnell et al., 2010). They offered a useful tool for identifying differences in flows between habitats based on landscape properties. Nevertheless, the trophic enrichment factor, which strongly affects source contributions, should be specifically measured in the laboratory (Herzka, 2005). Yet, since the TEF chosen was consistent with those measured in the laboratory for zoobenthivorous fish (Kostecki et al., 2012), our results should appropriately reflect the relative contribution of coastal and estuarine sources.

Another weakness of mixing models is their lack of accuracy in an environment where several sources present overlapping isotope ratios, which usually occurs in estuaries (Phillips et al., 2014). Nonetheless, as our objective was to relate the degree of connection of the sea to the contribution from coastal sources, uncertainties in determining the participation of low contribution overlapping estuarine sources were not an issue. The fact that the coastal SOM was not available in Suape is not likely to bias the model, since Suape and Sirinhaem are part of the same coastal region with homogeneous habitats (Assis et al., 2015). Furthermore, the anthropogenic pressures locally occurring in Suape are not expected to significantly alter the isotope ratios of its coastal area, since Suape is a small estuary. 
Contributions of basal sources were also influenced by seasonality. For example, marked seasonal variations in isotope ratios of $E$. argenteus occurred in Sirinhaem, the smallest estuary, due to the fact that in small tropical estuaries, where freshwater inputs are intermittent, seasonal nutrient inputs from terrestrial systems are favoured (Abrantes et al., 2015). Indeed, Sirinhaem location in the south, where rainfall is higher than in the north of the state (CPRH, 2003), allows for a large difference in freshwater supply between seasons. Differences in land use can also affect the seasonal intensity of inputs, but as Sirinhaem is the least anthropized estuary (Pelage et al., 2019), environmental fluctuations seems to be the main driver of seasonal patterns in this region. Hence, during the dry season, we could not run the model for Sirinhaem because consumers were not within the trophic polygon of sources suggesting the existence of unknown sources probably derived from the sea due to their enriched $\delta^{13} \mathrm{C}$ ratios. This implies that the low connection to the sea, inherent in the morphological characteristics of this enclosed lagoon, was not the factor that influenced the ecological connectivity during this season. Therein, high marine intrusion, fostered by high evaporation during the dry season and reduced river flow (Potter et al., 2010), may have caused a diet shift. During the rainy season, freshwater discharges reduce salinity, which is propitious for the development of polychaetes, while during the dry season, evaporation increases salinity, promoting the presence of marine benthic larvae (Chi-Espínola et al., 2018). This shift in marine invertebrates community could thus explain the higher $\delta^{13} \mathrm{C}$ values observed in Sirinhaem during the dry season.

Despite the lack of significant differences in $\delta^{13} \mathrm{C}$ values between seasons in Suape and in the Santa Cruz Channel, the seasonal shift observed in the models and with the ellipses may also be attributed to a difference in fish size within each estuary. Especially the differences in size between seasons could reflect the reproduction period of E. argenteus in the study area, which takes place at the beginning of the dry season and resulted the capture of smaller fish. Ontogenetic shifts were already observed in estuaries and hypersaline lagoons, where smaller specimens fed on zooplankton and larger individuals preyed on polychaetes ( Silva et al., 2016; Chi-Espínola et al., 2018).

\subsection{Implication for ecosystem functioning}

Greater variability in fish isotope ratios was measured at Sirinhaem during the rainy season, translated by a large ellipse area and a high variability in sources contributions. The size range of Sirinhaem fish during that 
season was narrow so its variability cannot be attributed to ontogenetic shifts. This may be due to resource partitioning to avoid interspecific competition in this closed estuary thanks to the plasticity of $E$. argenteus diet. Diet plasticity is generally associated with the quantification of the extent of the trophic niche, i.e. the set of resources that can be exploited by a population to maintain acceptable growth parameters (Polis, 1984). The ability to occupy wider trophic niches, thus feeding on a wide range of different items, ensures greater adaptability (Pörtner et al., 2010). The opportunistic behaviour of the silver mojarra was already registered (Chi-Espínola et al., 2018) and could promote species adaptation in closed lagoons where coastal foraging opportunities are limited. In tropical estuaries, spatial differences in the diet of $E$. argenteus have already been reported (Guedes et al., 2015). This habit could mitigate the adverse effects caused by natural or anthropic isolation between estuarine and coastal environments. However, more detailed health studies need to be conducted to assess the actual status of the fish population since variation in food web carbon sources, may cause differences in growth and condition (Isnard et al., 2015). Hence, variability in ecological connectivity and thus in diet could lead to variation in growth parameters.

Estuaries are suffering from various anthropic geomorphological modifications (Wetzel et al., 2012Du et al., 2016; Lechêne et al., 2018) which could alter the flows with adjacent coastal areas. Variations in ecological connectivity are likely to affect the functioning of ecosystems as they influence trophic pathways and energy flows between adjacent habitats. Besides, this study shows that ecological connectivity extent evolves with sea connection degree which controls essential environmental variables such as salinity and depth. These variables are key structuring factors for the distribution and abundance of species. Indeed, E. argenteus is a saltwater species, and in general Gerreidae abundance is usually positively correlated with salinity (Corrêa and Vianna, 2016). In the Santa Cruz Channel, where sea connection is strong, E. argenteus was the second most abundant species, while in the other two estuaries, Suape and Sirinhaem, the silver mojarra was not among the ten most abundant species (Merigot et al., 2017).

Indeed, the availability of the prey is controlled by environmental factors (Arula et al., 2012; Martino and Houde, 2010) and a narrow sea connection degree does influence estuarine resources access for saltwater species and coastal resources for estuarine resident. Reduced access to food resources resulting from habitat fragmentation is likely to exacerbate competition patterns (Hasegawa, 2017). In the case of a change 
in the sea connection such as during the construction of the port, coastal preys were less available for $E$. argenteus juveniles but the diet plasticity of this species may have allowed it to switch to a more estuarine diet, which may have increased competition with estuarine resident species.

In addition, marine migratory species whose juveniles use estuaries as nurseries and whose adults extensively use estuaries as feeding or reproductive grounds (e.g. Mugilidae, Gerreidae) represent an important yield for small-scale estuarine and coastal fisheries in tropical areas (Salas, 2011). Modification in ecological connectivity through alterations in estuarine morphology is susceptible to have adverse effects on these species and could have socioeconomical repercussion since they constitute essential source of proteins for local populations. In addition, they represent key prey for piscivorous fish, therefore a change in their abundance due to habitat degradation would have drastic repercussions on the ecosystem.

\section{Conclusion}

Differences in the degree of connection to the sea in estuaries influenced the origin of the organic matter supporting the diet of E. argenteus, chosen as an indicator of ecological connectivity with adjacent coastal habitats. Consequently, the geomorphological disturbances caused by the increasing human modification of estuaries are likely to seriously affect the functioning of these habitats, by altering the energy flows that support their food networks. The influence of seascape properties on biological processes is complex and assessing their effects on ecosystem services such as fisheries yields is a difficult but necessary task in a context of global change and dwindling resources. Preliminary multidisciplinary studies should be carried out before implementing any changes to the seascape that alter the connectivity between habitats, especially in the case of habitats of significant importance for migratory species. In addition, understanding the extent to which the restoration of geometric properties through eco-engineering allows for ecosystem resilience in terms of connectivity would be of interest.

\section{Acknowledgements}

This study was funded in part by the INCT (National Institute of Science and Technology, CNPq $\mathrm{n}^{\circ}$ 610013/2011-4) in Tropical Marine Environments - INCT-AmbTropic, the CNPq (National Council for Scientific and Technological Development, CNPq $n^{\circ} 479845 / 2013-1, n^{\circ} 407125 / 2013-2$ and $n^{\circ}$ 
207786/2015-1), and by CAPES (Coordination for the Improvement of Higher Education Personnel) for

providing the scholarship to the first author. We thank the members of BIOIMPACT Laboratory for their efforts on field campaigns and sampling procedures. This article is a contribution to the PADDLE project, which has received funding from the European Union's Horizon 2020 research and innovation programme under grant agreement No 734271, and to the LMI TAPIOCA. We also thank the professors A. Bertrand, W.

Severi and F. Marcante for personal advices during the preparation of the manuscript and to the anonymous reviewers who helped in the improvement of the work.

\section{References}

Abrantes, K.G., Barnett, A., Baker, R., Sheaves, M., 2015. Habitat-specific food webs and trophic interactions supporting coastal-dependent fishery species: an Australian case study. Rev Fish Biol Fisheries 25, 337-363. https://doi.org/10.1007/s11160-015-9385-y

APAC, 2020. Meteorologia |APAC - Agência Pernambucana de Águas e Clima [WWW Document]. URL http://www.apac.pe.gov.br/meteorologia/ (accessed 8.22.20).

Arula, T., Kotta, J., Lankov, A., Simm, M., Põlme, S., 2012. Diet composition and feeding activity of larval spring-spawning herring: importance of environmental variability. Journal of Sea Research 68, 33-40.

Assis, H.M.B. de, Valle, M.M., Gomes, R.B., Salviano, K. dos S., Pereira, L.B.F., 2015. Carta de caracterização dos agregados marinhos da plataforma continental rasa do estado de Pernambuco.

Assunção, R.V., Silva, A.C., Roy, A., Bourlès, B., Silva, C.H.S., Ternon, J.-F., Araujo, M., Bertrand, A., 2020. 3D characterisation of the thermohaline structure in the southwestern tropical Atlantic derived from functional data analysis of in situ profiles. Progress in Oceanography 102399.

Beger, M., Grantham, H.S., Pressey, R.L., Wilson, K.A., Peterson, E.L., Dorfman, D., Mumby, P.J., Lourival, R., Brumbaugh, D.R., Possingham, H.P., 2010. Conservation planning for connectivity across marine, freshwater, and terrestrial realms. Biological Conservation 143, 565-575.

Berkström, C., Jörgensen, T.L., Hellström, M., 2013. Ecological connectivity and niche differentiation between two closely related fish species in the mangrove-seagrass-coral reef continuum. Marine Ecology Progress Series 477, 201-215.

Borges, C.P., 2011. Comunidade fitoplanctônica do estuário do rio Massangana (PernambucoBrasil).

Bouchon-Navaro, Y., Bouchon, C., Kopp, D., Louis, M., 2006. Weight-length relationships for 50 fish species collected in seagrass beds of the Lesser Antilles. Journal of Applied Ichthyology 22, 322-324.

Burgess, S.C., Nickols, K.J., Griesemer, C.D., Barnett, L.A., Dedrick, A.G., Satterthwaite, E.V., Yamane, L., Morgan, S.G., White, J.W., Botsford, L.W., 2014. Beyond connectivity: how empirical methods can quantify population persistence to improve marine protected-area design. Ecological Applications 24, 257-270.

Carvalho, D.R., Castro, D.M.P., Callisto, M., Moreira, M.Z., Pompeu, P.S., 2017. The trophic structure of fish communities from streams in the Brazilian Cerrado under different land uses: an approach using stable isotopes. Hydrobiologia 795, 199-217. 
Caut, S., Angulo, E., Courchamp, F., 2009. Variation in discrimination factors ( $\Delta 15 \mathrm{~N}$ and $\Delta 13 \mathrm{C})$ : the effect of diet isotopic values and applications for diet reconstruction. Journal of Applied Ecology 46, 443-453.

Chaves, P., Bouchereau, J.-L., 2000. Use of mangrove habitat for reproductive activity by the fish assemblage in the Guaratuba Bay, Brazil. Oceanologica Acta 23, 273-280.

Chen, W.-J., Ruiz-Carus, R., Ortí, G., 2007. Relationships among four genera of mojarras (Teleostei: Perciformes: Gerreidae) from the western Atlantic and their tentative placement among percomorph fishes. Journal of Fish Biology 70, 202-218.

Chi-Espínola, A.A., Vega-Cendejas, M.E., Canto-Maza, W.G., 2018a. Feeding habits of the mojarras (Gerreidae) population in the hyperhaline lagoon system of Ría Lagartos, Yucatan, Mexico. Latin American Journal of Aquatic Research 46.

Chi-Espínola, A.A., Vega-Cendejas, M.E., Canto-Maza, W.G., 2018b. Feeding habits of the mojarras (Gerreidae) population in the hyperhaline lagoon system of Ría Lagartos, Yucatan, Mexico. Latin american journal of aquatic research 46, 810-819.

Choy, E.J., Richard, P., Kim, K.-R., Kang, C.-K., 2009. Quantifying the trophic base for benthic secondary production in the Nakdong River estuary of Korea using stable $\mathrm{C}$ and $\mathrm{N}$ isotopes. Journal of Experimental Marine Biology and Ecology 382, 18-26.

Corrêa, B., Vianna, M., 2016. Spatial and temporal distribution patterns of the silver mojarra Eucinostomus argenteus (Perciformes: Gerreidae) in a tropical semi-enclosed bay. Journal of fish biology 89, 641-660.

CPRH, 2003. Diagnóstico socioambiental do litoral norte de Pernambuco. Recife: Agência Estadual do Meio Ambiente.

CPRH, 2001. Diagnóstico Socioambiental: Litoral Sul de Pernambuco. Recife: Agência Estadual do Meio Ambiente 89.

Du, J.-L., Yang, S.-L., Feng, H., 2016. Recent human impacts on the morphological evolution of the Yangtze River delta foreland: A review and new perspectives. Estuarine, Coastal and Shelf Science 181, 160-169. https://doi.org/10.1016/j.ecss.2016.08.025

Elliott, M., Mander, L., Mazik, K., Simenstad, C., Valesini, F., Whitfield, A., Wolanski, E., 2016. Ecoengineering with Ecohydrology: Successes and failures in estuarine restoration.

Estuarine, Coastal and Shelf Science 176, 12-35. https://doi.org/10.1016/j.ecss.2016.04.003

Elliott, M., McLusky, D.S., 2002. The Need for Definitions in Understanding Estuaries. Estuarine, Coastal and Shelf Science 55, 815-827. https://doi.org/10.1006/ecss.2002.1031

Flemming, B.W., 2011. 3.02 Geology, Morphology, and Sedimentology of Estuaries and Coasts. Treatise on Estuarine and Coastal Science. Academic Press, Waltham 7-38.

França, S., Vasconcelos, R.P., Tanner, S., Máguas, C., Costa, M.J., Cabral, H.N., 2011. Assessing food web dynamics and relative importance of organic matter sources for fish species in two Portuguese estuaries: A stable isotope approach. Marine Environmental Research 72, 204215. https://doi.org/10.1016/j.marenvres.2011.09.001

Franco, T.P., Neves, L.M., Teixeira, T.P., Araújo, F.G., 2012. Patterns of spatial distribution of five species of mojarras (Actinopterygii: Gerreidae) in a small tropical estuary in south-eastern Brazil. Journal of the Marine Biological Association of the United Kingdom 92, 1217-1225.

Fry, B., 2006. Stable isotope ecology. Springer.

Gonzalez, J.G., Ménard, F., Le Loc'h, F., de Andrade, H.A., Viana, A.P., Ferreira, V., Frédou, F.L., Lira, A.S., Munaron, J.-M., Frédou, T., 2019. Trophic resource partitioning of two snook fish species (Centropomidae) in tropical estuaries in Brazil as evidenced by stable isotope analysis. Estuarine, Coastal and Shelf Science 226, 106287.

Green, B.C., Smith, D.J., Underwood, G.J., 2012. Habitat connectivity and spatial complexity differentially affect mangrove and salt marsh fish assemblages. Marine Ecology Progress Series 466, 177-192.

Guedes, A.P.P., Araújo, F.G., Pessanha, A.L., Milagre, R.R., 2015. Partitioning of the feeding niche along spatial, seasonal and size dimensions by the fish community in a tropical B ay in $\mathrm{S}$ outheastern B razil. Marine Ecology 36, 38-56. 
Guimarães, A.S., Travassos, P., Souza Filho, P.W.M.E., Gonçalves, F.D., Costa, F., 2010. Impact of aquaculture on mangrove areas in the northern Pernambuco Coast (Brazil) using remote sensing and geographic information system. Aquaculture Research 41, 828-838.

Hasegawa, K., 2017. Displacement of native white-spotted charr Salvelinus leucomaenis by nonnative brown trout Salmo trutta after resolution of habitat fragmentation by a migration barrier. Journal of Fish Biology 90, 2475-2479. https://doi.org/10.1111/jfb.13320

Herzka, S.Z., 2005a. Assessing connectivity of estuarine fishes based on stable isotope ratio analysis. Estuarine, Coastal and Shelf Science 64, 58-69.

Herzka, S.Z., 2005b. Assessing connectivity of estuarine fishes based on stable isotope ratio analysis. Estuarine, Coastal and Shelf Science 64, 58-69.

Hussey, N.E., MacNeil, M.A., McMeans, B.C., Olin, J.A., Dudley, S.F., Cliff, G., Wintner, S.P., Fennessy, S.T., Fisk, A.T., 2014. Rescaling the trophic structure of marine food webs. Ecology letters 17, 239-250.

Isnard, E., Tournois, J., McKenzie, D.J., Ferraton, F., Bodin, N., Aliaume, C., Darnaude, A.M., 2015. Getting a Good Start in Life? A Comparative Analysis of the Quality of Lagoons as Juvenile Habitats for the Gilthead Seabream Sparus aurata in the Gulf of Lions. Estuaries and Coasts 38, 1937-1950. https://doi.org/10.1007/s12237-014-9939-6

Jackson, A., Parnell, A., Jackson, M.A., 2017. Package 'SIBER.' Stable Isotope Bayesian Ellipses in $\mathrm{R}$.

Jackson, A.L., Inger, R., Parnell, A.C., Bearhop, S., 2011. Comparing isotopic niche widths among and within communities: SIBER-Stable Isotope Bayesian Ellipses in R. Journal of Animal Ecology 80, 595-602.

Kostecki, Caroline, Roussel, J.M., Desroy, N., Roussel, G., Lanshere, J., Le Bris, H., Le Pape, O., 2012. Trophic ecology of juvenile flatfish in a coastal nursery ground: contributions of intertidal primary production and freshwater particulate organic matter. Marine Ecology Progress Series 449, 221-232.

Kostecki, C., Roussel, J.M., Desroy, N., Roussel, G., Lanshere, J., Le Bris, H., Le Pape, O., 2012. Trophic ecology of juvenile flatfish in a coastal nursery ground: contributions of intertidal primary production and freshwater particulate organic matter. Marine Ecology Progress Series 449, 221-232.

Le, D.Q., Tanaka, K., Hii, Y.S., Sano, Y., Nanjo, K., Shirai, K., 2018. Importance of seagrassmangrove continuum as feeding grounds for juvenile pink ear emperor Lethrinus lentjan in Setiu Lagoon, Malaysia: Stable isotope approach. Journal of Sea Research 135, 1-10.

Lechêne, A., Boët, P., Laffaille, P., Lobry, J., 2018. Nekton communities of tidally restored marshes: A whole-estuary approach. Estuarine, Coastal and Shelf Science 207, 368-382.

Lira, A., Angelini, R., Le Loc'h, F., Ménard, F., Lacerda, C., Frédou, T., Frédou, F.L., 2018. Trophic flow structure of a neotropical estuary in northeastern Brazil and the comparison of ecosystem model indicators of estuaries. Journal of Marine Systems 182, 31-45.

Lobry, J., David, V., Pasquaud, S., Lepage, M., Sautour, B., Rochard, E., 2008. Diversity and stability of an estuarine trophic network. Mar. Ecol. Prog. Ser. 358, 13-25. https://doi.org/10.3354/meps07294

Manso, V. do A.V., Correa, I.C.S., GUERRA, N., 2003. Morfologia e sedimentologia da plataforma continental interna entre as Praias Porto de Galinhas e Campos-Litoral Sul de Pernambuco, Brasil. Pesquisas em geociências 30, 17-25.

Martino, E.J., Houde, E.D., 2010. Recruitment of striped bass in Chesapeake Bay: spatial and temporal environmental variability and availability of zooplankton prey. Marine Ecology Progress Series 409, 213-228.

Medeiros, C., Kjerfve, B., 1993. Hydrology of a tropical estuarine system: Itamaracá, Brazil. Estuarine, Coastal and Shelf Science 36, 495-515.

Medeiros, C., Kjerfve, B., Araujo, M., Neumann-Leitão, S., 2001. The Itamaracá estuarine ecosystem, Brazil, in: Coastal Marine Ecosystems of Latin America. Springer, pp. 71-81. 
Merigot, B., Frédou, F.L., Viana, A.P., Ferreira, B.P., Junior, E. do N.C., da Silva Júnior, C.B., Frédou, T., 2017. Fish assemblages in tropical estuaries of northeast Brazil: A multicomponent diversity approach. Ocean \& coastal management 143, 175-183.

Moens, T., Luyten, C., Middelburg, J.J., Herman, P.M., Vincx, M., 2002. Tracing organic matter sources of estuarine tidal flat nematodes with stable carbon isotopes. Marine Ecology Progress Series 234, 127-137.

Moura, A.R.L.U., Candeias, A.L.B., 2009. A multi-temporal remote sensing and gis based inventory of the mangroves at itamaracá estuarine system, Northeastern Brazil. Tropical Oceanography-ISSN: 1679-3013 37.

Mumby, P.J., Edwards, A.J., Arias-González, J.E., Lindeman, K.C., Blackwell, P.G., Gall, A., Gorczynska, M.I., Harborne, A.R., Pescod, C.L., Renken, H., 2004. Mangroves enhance the biomass of coral reef fish communities in the Caribbean. Nature 427, 533.

Muniz, K., Neto, B. de B., Macêdo, S.J., Filho, W.C.P., 2005. Hydrological impact of the port complex of Suape on the Ipojuca River (Pernambuco-Brazil). Journal of coastal research 909-914.

Nagelkerken, I., 2009. Ecological connectivity among tropical coastal ecosystems. Springer.

Ogden, J.C., 1997. Ecosystem interactions in the tropical coastal seascape.

Olds, A.D., Nagelkerken, I., Huijbers, C.M., Gilby, B.L., Pittman, S.J., Schlacher, T.A., 2017a. Connectivity in Coastal Seascapes, in: Seascape Ecology. John Wiley \& Sons Ltd., pp. 261292.

Olds, A.D., Nagelkerken, I., Huijbers, C.M., Gilby, B.L., Pittman, S.J., Schlacher, T.A., 2017b. Connectivity in Coastal Seascapes, in: Seascape Ecology. John Wiley \& Sons Ltd., pp. 261292.

Parnell, A.C., Inger, R., Bearhop, S., Jackson, A.L., 2010. Source partitioning using stable isotopes: coping with too much variation. PloS one 5.

Pasquaud, S., Elie, P., Jeantet, C., Billy, I., Martinez, P., Girardin, M., 2008. A preliminary investigation of the fish food web in the Gironde estuary, France, using dietary and stable isotope analyses. Estuarine, Coastal and Shelf Science 78, 267-279.

Pasquaud, S., Pillet, M., David, V., Sautour, B., Elie, P., 2010. Determination of fish trophic levels in an estuarine system. Estuarine, Coastal and Shelf Science 86, 237-246.

Pelage, L., Domalain, G., Lira, A.S., Travassos, P., Frédou, T., 2019. Coastal land use in Northeast Brazil: mangrove coverage evolution over three decades. Tropical Conservation Science 12, 1940082918822411.

Phillips, D.L., Gregg, J.W., 2003. Source partitioning using stable isotopes: coping with too many sources. Oecologia 136, 261-269.

Phillips, D.L., Inger, R., Bearhop, S., Jackson, A.L., Moore, J.W., Parnell, A.C., Semmens, B.X., Ward, E.J., 2014. Best practices for use of stable isotope mixing models in food-web studies. Canadian Journal of Zoology 92, 823-835.

Pinnegar, J.K., Polunin, N.V.C., 1999. Differential fractionation of $\delta 13 \mathrm{C}$ and $\delta 15 \mathrm{~N}$ among fish tissues: implications for the study of trophic interactions. Functional ecology 13, 225-231.

Pinto, M.F., da Silva Mourão, J., Alves, R.R.N., 2013. Ethnotaxonomical considerations and usage of ichthyofauna in a fishing community in Ceará State, Northeast Brazil. Journal of ethnobiology and ethnomedicine 9, 17.

Polis, G.A., 1984. Age structure component of niche width and intraspecific resource partitioning: can age groups function as ecological species? The American Naturalist 123, 541-564.

Pörtner, H.-O., Schulte, P.M., Wood, C.M., Schiemer, F., 2010. Niche dimensions in fishes: an integrative view. Physiological and Biochemical Zoology 83, 808-826.

Post, D.M., 2002. Using stable isotopes to estimate trophic position: models, methods, and assumptions. Ecology 83, 703-718.

Potter, I.C., Chuwen, B.M., Hoeksema, S.D., Elliott, M., 2010. The concept of an estuary: a definition that incorporates systems which can become closed to the ocean and hypersaline. Estuarine, Coastal and Shelf Science 87, 497-500. 
Quezada-Romegialli, C., Jackson, A.L., Hayden, B., Kahilainen, K.K., Lopes, C., Harrod, C., 2018. tRophicPosition, an R package for the Bayesian estimation of trophic position from consumer stable isotope ratios. Methods in Ecology and Evolution 9, 1592-1599.

Quinamo, T. dos S., 2006. Pesca artesanal e meio ambiente em áreas de manguezais no complexo estuarino-costeiro de Itamaracá, Pernambuco: o caso de Itapissuma.

R Core Team, 2019. R: A Language and Environment for Statistical Computing (Version 3.5. 2, R Foundation for Statistical Computing, Vienna, Austria, 2018).

Ramos, J.A., Barletta, M., Costa, M.F., 2012. Ingestion of nylon threads by Gerreidae while using a tropical estuary as foraging grounds. Aquatic Biology 17, 29-34.

Ramos, J.A.A., Barletta, M., Dantas, D.V., Costa, M.F., 2016. Seasonal and spatial ontogenetic movements of Gerreidae in a Brazilian tropical estuarine ecocline and its application for nursery habitat conservation. Journal of fish biology 89, 696-712.

Reis-Santos, P., Tanner, S.E., Aboim, M.A., Vasconcelos, R.P., Laroche, J., Charrier, G., Pérez, M., Presa, P., Gillanders, B.M., Cabral, H.N., 2018. Reconciling differences in natural tags to infer demographic and genetic connectivity in marine fish populations. Scientific reports 8 , 10343.

Salas, S. (Ed.), 2011. Coastal fisheries of Latin America and the Caribbean, FAO fisheries and aquaculture technical paper. Food and Agriculture Organization of the United Nations, Rome.

Santos, M.A., Costa, W.D., 1974. Complexo industrial de Suape: estudo hidrogeológico preliminar. Simpósio de Geologia do Nordeste. Sociedade Brasileira de Geologia do Nordeste, Recife.[Links] 49-69.

Selleslagh, J., Blanchet, H., Bachelet, G., Lobry, J., 2015. Feeding habitats, connectivity and origin of organic matter supporting fish populations in an estuary with a reduced intertidal area assessed by stable isotope analysis. Estuaries and coasts 38, 1431-1447.

Sheaves, M., 2009. Consequences of ecological connectivity: the coastal ecosystem mosaic. Marine Ecology Progress Series 391, 107-115.

Silva, J.B., Galvíncio, J.D., de Barros Corrêa, A.C., da Silva, D.G., Machado, C.C.C., 2011. Classificação Geomorfológica dos Estuários do Estado de Pernambuco (Brasil) com Base em Imagens do LANDSAT 5/TM (Geomorphologic Classification of Estuaries of the State of Pernambuco (Brazil) Based on Landsat 5 TM Images). Revista Brasileira de Geografia Física 4, 118-133.

Silva, R.S., Carvalho, K.D., Pessanha, A.L., 2016. Distribution and feeding ecology of three juvenile mojarras in a hypersaline tropical estuary in Northeastern Brazil. Marine ecology 37, 1266-1281.

Stock, B.C., Jackson, A.L., Ward, E.J., Parnell, A.C., Phillips, D.L., Semmens, B.X., 2018. Analyzing mixing systems using a new generation of Bayesian tracer mixing models. PeerJ 6, e5096.

Stock, B.C., Semmens, B.X., 2015. MixSIAR.

Valença, S., Maria do Carmo, M.S., Ramos, D., Cavalcanti, C., 2010. Prospective scenarios of the environmental management of the tourist destination of Porto de Galinhas based on the enlargement of the industrial and portuary complex of Suape, Pernambuco. Management of Environmental Quality: An International Journal.

Vasconcellos, R.M., Gomes-Gonçalves, R.S., Santos, J.N.S., Cruz Filho, A.G., Araújo, F.G., 2018. Do closely related species share of feeding niche along growth? Diets of three sympatric species of the mojarras (Actinopterygii: Gerreidae) in a tropical bay in southeastern Brazil. Environmental Biology of Fishes 101, 949-962.

Vasconcelos, R.P., Reis-Santos, P., Maia, A., Fonseca, V., França, S., Wouters, N., Costa, M.J., Cabral, H.N., 2010. Nursery use patterns of commercially important marine fish species in estuarine systems along the Portuguese coast. Estuarine, Coastal and Shelf Science 86, 613624. 
Wetzel, M.A., von der Ohe, P.C., Manz, W., Koop, J.H.E., Wahrendorf, D.-S., 2012. The ecological quality status of the Elbe estuary. A comparative approach on different benthic biotic indices applied to a highly modified estuary. Ecological Indicators, Assessing ecological quality in estuarine and coastal ecosystems 19, 118-129. https://doi.org/10.1016/j.ecolind.2011.08.007

Whitfield, A., Elliott, M., 2011. Ecosystem and Biotic Classifications of Estuaries and Coasts, in: Treatise on Estuarine and Coastal Science. Elsevier, pp. 99-124.

https://doi.org/10.1016/B978-0-12-374711-2.00108-X

Whitney, E.J., Beaudreau, A.H., Howe, E.R., 2018. Using Stable Isotopes to Assess the Contribution of Terrestrial and Riverine Organic Matter to Diets of Nearshore Marine Consumers in a Glacially Influenced Estuary. Estuaries and Coasts 41, 193-205. https://doi.org/10.1007/s12237-017-0260-z

SUPPLEMENTARY MATERIAL:

\begin{tabular}{lllll} 
Environment & Gear & net height $(\mathbf{m})$ & net length $(\mathbf{m})$ & Mesh $(\mathbf{m m})$ \\
\hline \multirow{3}{*}{ Estuary } & Block net & 1.9 & 80 & 70 \\
& Beach seine & 5.0 & 180 & 25 \\
& Seine net & 8.0 & 75 & 10 \\
\multirow{3}{*}{ Coast } & Gill net & 1.5 & 200 & 50 \\
& Trawler & 6.1 & 10 & 25 \\
& Bottom trawl & 10.0 & 28 & 25 \\
\hline
\end{tabular}

Supplementary Table 1: Characteristics of the fishing gears used to capture the fish in the different environment.

\begin{tabular}{|c|c|c|c|c|c|c|c|c|c|}
\hline \multirow[t]{2}{*}{ Estuary } & & \multicolumn{4}{|c|}{ DRY } & \multicolumn{4}{|c|}{ RAINY } \\
\hline & & $\mathrm{n}$ & $\mathrm{TL}(\mathrm{cm})$ & $\delta^{13} \mathrm{C}(\% \circ)$ & $\delta^{15} \mathrm{~N}(\%)$ & $\mathrm{n}$ & $\mathrm{TL}(\mathrm{cm})$ & $\delta^{13} \mathrm{C}(\% \circ)$ & $\delta^{15} \mathrm{~N}(\% \circ)$ \\
\hline $\begin{array}{l}\text { Santa } \\
\text { Channel }\end{array}$ & Cruz & 10 & $8.2-9.6$ & $-16.3 \pm 1.0$ & $9.3 \pm 0.6$ & 10 & $11.9-14.6$ & $-16.9 \pm 1.0$ & $11.0 \pm 1.0$ \\
\hline Suape & & 7 & $3.6-5.2$ & $-18.6 \pm 0.9$ & $10.6 \pm 1.1$ & 6 & $5.2-14.1$ & $-19.8 \pm 1.3$ & $9.7 \pm 0.5$ \\
\hline Sirinhaem & & 4 & $7.4-16.6$ & $-14.0 \pm 2.4$ & $10.3 \pm 0.3$ & 9 & $7.7-9.5$ & $-21.2 \pm 3.9$ & $9.3 \pm 1.1$ \\
\hline Coast & & 10 & $9.4-15.0$ & $-16.9 \pm 2.27$ & $11.2 \pm 0.8$ & - & & & \\
\hline
\end{tabular}

Supplementary Table 2: Number of samples (n), Total length (TL), Isotopic means ( \pm S.D.) of carbon $\left(\delta^{13} C\right)$, nitrogen $\left(\delta^{15} \mathrm{~N}\right)$ of the fish collected in the estuarine and coastal areas during the dry and the rainy season.

\begin{tabular}{|c|c|c|c|c|c|c|c|c|}
\hline \multirow{2}{*}{ Source } & \multirow{2}{*}{ Environment } & \multirow{2}{*}{ Area } & \multicolumn{3}{|c|}{ DRY } & \multicolumn{3}{|c|}{ RAINY } \\
\hline & & & $n$ & $\delta^{13} \mathrm{C}$ & $\delta^{15} \mathrm{~N}$ & $n$ & $\delta^{13} \mathrm{C}$ & $\delta^{15} \mathrm{~N}$ \\
\hline \multirow{5}{*}{ SOM } & \multirow{3}{*}{ Estuary } & SCC & 6 & $-23.8 \pm 1.4$ & $4.5 \pm 1.0$ & 6 & $-24.0 \pm 1.0$ & $4.2 \pm 0.7$ \\
\hline & & SUAPE & 6 & $-25.3 \pm 0.5$ & $4.2 \pm 0.9$ & 6 & $-26.0 \pm 0.4$ & $2.7 \pm 0.6$ \\
\hline & & SIR & 6 & $-25.9 \pm 0.7$ & $4.7 \pm 0.5$ & 6 & $-25.0 \pm 1.0$ & $4.0 \pm 0.3$ \\
\hline & \multirow{2}{*}{ Coast } & SCC & 6 & $-21.2 \pm 1.2$ & $5.5 \pm 1.2$ & 6 & $-20.6 \pm 1.1$ & $5.8 \pm 1.1$ \\
\hline & & Sir & 6 & $-16.8 \pm 0.4$ & $3.9 \pm 0.6$ & 6 & $15.9 \pm 0.1$ & $3.3 \pm 0.2$ \\
\hline \multirow{3}{*}{$\begin{array}{l}\text { Algae } \\
\text { (Ulva sp) } \\
\text { Algae } \\
\text { Sargassum sp. }\end{array}$} & Estuary & SCC & 3 & $-23.4 \pm 0.4$ & $8.9 \pm 0.2$ & 3 & $-23.0 \pm 0.4$ & $6.3 \pm 0.2$ \\
\hline & \multirow{2}{*}{ Estuary } & SUAPE & 3 & $-18.2 \pm 0.3$ & $8.9 \pm 0.1$ & 3 & $-16.5 \pm 2.3$ & $7.0 \pm 0.2$ \\
\hline & & SIR & & - & - & 3 & $-16.8 \pm 1.3$ & $5.4 \pm 0.4$ \\
\hline \multirow{3}{*}{$\begin{array}{l}\text { Microphyto } \\
\text { benthos }\end{array}$} & \multirow{3}{*}{ Estuary } & SCC & 3 & $-20.3 \pm 0.2$ & $3.9 \pm 0.4$ & 2 & $-19.6 \pm 2.8$ & $2.7 \pm 0.4$ \\
\hline & & SUAPE & 1 & -26.4 & 4.7 & - & & \\
\hline & & SIR & 4 & $-24.8 \pm 0.7$ & $4.2 \pm 0.5$ & 3 & $-22.0 \pm 1.1$ & $5.9 \pm 0.2$ \\
\hline Seagrass & Estuary & SCC & 3 & $-27.6 \pm 0.6$ & $2.4 \pm 0.5$ & 3 & $-28.0 \pm 0.3$ & $1.4 \pm 0.4$ \\
\hline
\end{tabular}




\begin{tabular}{lllllllll} 
Mangrove & & SCC & 3 & $-27.8 \pm 0.7$ & $3.0 \pm 0.9$ & 3 & $-27.4 \pm 0.2$ & $1.8 \pm 1.2$ \\
& Estuary & SUAPE & 3 & $-27.1 \pm 0.5$ & $1.5 \pm 0.5$ & 3 & $-27.1 \pm 0.7$ & $1.5 \pm 0.5$ \\
& & SIR & 3 & $-28.5 \pm 0.1$ & $1.8 \pm 1.9$ & 3 & $-28.5 \pm 0.5$ & $2.1 \pm 0.8$ \\
\multirow{3}{*}{ C. rhizophorae } & \multirow{2}{*}{ Estuary } & SCC & 4 & $-23.2 \pm 0.4$ & $7.7 \pm 0.4$ & 3 & $-22.5 \pm 0.1$ & $8.2 \pm 0.1$ \\
& & SUAPE & 3 & $-19.3 \pm 0.8$ & $7.1 \pm 0.3$ & 3 & $-19.6 \pm 1.7$ & $8.0 \pm 0.2$ \\
& & SIR & 6 & $-16.1 \pm 0.4$ & $6.8 \pm 0.4$ & 6 & $-20.4 \pm 0.2$ & $8.0 \pm 0.2$
\end{tabular}

Supplementary Table 3: Number of samples $(n)$ and isotopic means ( \pm S.D.) of carbon $(\delta 13 C)$, nitrogen $(\delta 15 N)$ of basal sources and the oyster $C$.rhizophorae during dry and rainy season in the Santa Cruz Channel (SCC), Suape and Sirinhaem (SIR).

\begin{tabular}{lllll}
\hline Estuary & Variable & P value & Rho & S \\
\hline ALL & $\delta^{15} \mathrm{~N}$ & NS & - & 11975 \\
& $\delta^{13} \mathrm{C}$ & NS & - & 13919 \\
Santa Cruz & $\delta^{15} \mathrm{~N}$ & 0.00236 & 0.6402471 & 478.47 \\
Channel & $\delta^{13} \mathrm{C}$ & $\mathrm{NS}$ & & 1795.9 \\
Suape & $\delta^{15} \mathrm{~N}$ & $\mathrm{NS}$ & - & 428.35 \\
& $\delta^{13} \mathrm{C}$ & 0.009764 & -0.6850933 & 613.37 \\
Sirinhaém & $\delta^{15} \mathrm{~N}$ & $\mathrm{NS}$ & - & 227.62 \\
& $\delta^{13} \mathrm{C}$ & $\mathrm{NS}$ & - & 232.64 \\
\hline
\end{tabular}

Supplementary Table 4: Results of the Spearman ranking tests between the total length off the fish and the the $\delta^{13} \mathrm{C} / \delta^{15} \mathrm{~N}$ of fish in all the estuaries together as well as in each estuary (Santa Cruz Channel, Sirinhaem and Suape). NS: Not Significant ( $p$ value $>0.005$ ).

\begin{tabular}{|c|c|c|c|}
\hline Estuary & Variable & p value & W \\
\hline ALL & $\delta^{15} \mathrm{~N}(\%)$ & NS & 250 \\
\hline $\begin{array}{c}\text { Santa Cruz Chan } \\
\text { nel }\end{array}$ & $\delta^{15} \mathrm{~N}(\%)$ & 0.0007253 & 8 \\
\cline { 2 - 4 } & $\delta^{13} \mathrm{C}(\%)$ & $\mathrm{NS}$ & 66 \\
\hline \multirow{2}{*}{ Suape } & $\delta^{15} \mathrm{~N}(\% \circ)$ & $\mathrm{NS}$ & 35 \\
\cline { 2 - 4 } & $\delta^{13} \mathrm{C}(\% \circ)$ & $\mathrm{NS}$ & 33 \\
\hline \multirow{2}{*}{ Sirinhaem } & $\delta^{15} \mathrm{~N}(\% \circ)$ & $\mathrm{NS}$ & 28 \\
\cline { 2 - 4 } & $\delta^{13} \mathrm{C}(\% \circ)$ & 0.03357 & 32 \\
\hline
\end{tabular}

Supplementary Table 5: Results of the Mann-Whitney tests verifying seasonal differences in the $\delta^{13} \mathrm{C} / \delta^{15} \mathrm{~N}$ of fish in each estuary (Santa Cruz Channel, Sirinhaem and Suape). NS: Not Significant ( $p$ value $>0.005$ ).

\begin{tabular}{|c|c|c|c|}
\hline \multirow{2}{*}{ Source } & \multirow{2}{*}{ Estuary } & \multicolumn{2}{|c|}{ Contribution } \\
\hline & & DRY & RAINY \\
\hline \multirow[t]{3}{*}{ Algae } & Santa Cruz Channel & 0.051 & 0.096 \\
\hline & Suape & 0.256 & 0.182 \\
\hline & Sirinhaem & - & 0.156 \\
\hline \multirow[t]{3}{*}{ Mangrove } & Santa Cruz Channel & 0.031 & 0.050 \\
\hline & Suape & 0.123 & 0.161 \\
\hline & Sirinhaem & - & 0.246 \\
\hline \multirow[t]{3}{*}{ Microphytoplancton } & Santa Cruz Channel & 0.115 & 0.116 \\
\hline & Suape & 0.136 & 0.165 \\
\hline & Sirinhaem & - & 0.181 \\
\hline
\end{tabular}




$\begin{array}{llll}\text { Seagrass } & \text { Santa Cruz Channel } & 0.233 & 0.133 \\ \text { SOM } & \text { Santa Cruz Channel } & 0.055 & 0.084 \\ & \text { Suape } & 0.157 & 0.203 \\ \text { SOM Coast } & \text { Sirinhaem } & - & 0.270 \\ & \text { Santa Cruz Channel } & 0.514 & 0.521 \\ & \text { Suape } & 0.329 & 0.290 \\ & \text { Sirinhaem } & - & 0.146\end{array}$

Supplementary Table 6: Mean of the relative contributions of the organic matter sources in each of the estuaries during the rainy and the dry season. 


\section{Highlights}

- The origin of the organic matter underlying food webs was investigated in three estuaries with distinct morphologies

- Coastal organic matter contributed more to fish diet when landscape properties enabled a better sea-connection

- Estuary morphology regulates interactions between estuaries and their adjacent coast 


\section{Declaration of interests}

$\bigotimes$ The authors declare that they have no known competing financial interests or personal relationships that could have appeared to influence the work reported in this paper.

$\square$ The authors declare the following financial interests/personal relationships which may be considered as potential competing interests: 